\title{
ASSESSMENT OF PATIENTS' SATISFACTION LEVEL WITH NURSING CARE IN THE DEPARTMENT OF NEUROLOGY
}

\author{
Katarzyna Wojtas ${ }^{1 \mathrm{D}, \mathrm{E}, \mathrm{F}}$, Alicja Kamińska ${ }^{2 \mathrm{~A}, \mathrm{C}, \mathrm{D}, \mathrm{E}, \mathrm{F}}$, Alicja Kucharczyk ${ }^{3 \mathrm{~A}, \mathrm{~B}, \mathrm{C}}$
}

'Department of Clinical Nursing, Faculty of Health Sciences, Jagiellonian University Medical College, Cracow, Poland

2Laboratory of Theory and Fundamentals of Nursing, Faculty of Health Sciences, Jagiellonian University Medical College, Cracow, Poland

${ }^{3}$ Neurology Department with Stroke Unit, $5^{\text {th }}$ Military Clinical Hospital with Polyclinic, Cracow, Poland

Authors' contribution:

A. Study design/planning • B. Data collection/entry $\bullet$ C. Data analysis/statistics $\bullet$ D. Data interpretation $\bullet$ E. Preparation of manuscript $\bullet$ F. Literature analysis/search $\bullet$ G. Funds collection

\author{
Address for correspondence: \\ Dr Alicja Kamińska \\ Laboratory of Theory and Fundamentals \\ of Nursing \\ Faculty of Health Sciences \\ Jagiellonian University Medical College \\ Cracow, Poland \\ e-mail: alicja.kaminska@uj.edu.pl \\ SUBMITTED: 02.09.2021 \\ ACCEPTED: 16.09 .2021 \\ DOI: https://doi.org/10.5114/ppiel.2021.110448
}

\begin{abstract}
Introduction: Assessment of satisfaction with nursing care is the result of evaluation of nursing manner, instrumental activities, and contact expressing kindness and care.

Aim of the study: To assess patients' satisfaction with nursing care during hospitalization in a neurology department. Material and methods: A diagnostic survey method was conducted among 81 patients treated in the $5^{\text {th }}$ Military Clinical Hospital with Polyclinic in Cracow. The research tools included the Newcastle Satisfaction with Nursing Scale and the author's questionnaire. Statistical analysis was performed using Statistica 10 software, and the significance level was adopted as $p<0.05$.

Results: The mean nursing experience score was 77.69, and the mean nursing satisfaction score was 83.67. A significant difference in nursing experience score according to the respondents' education $(p=0.03)$, work activity and study $(p=0.00)$, and a difference in satisfaction score according to marital status $(p=0.02)$ were confirmed. There is a correlation between experiences and satisfaction with nursing care and conditions on the ward and nurses' behaviour. There was no confirmed relationship between nursing experience and satisfaction scores and gender, the age of the subjects, and the number of nurses on duty.

Conclusions: Satisfaction with care depends on various factors that are directly or indirectly related to the nurse's job. Knowing the patients' satisfaction with nursing care is extremely important in order to take measures aimed at eliminating factors that reduce such satisfaction.
\end{abstract}

Key words: satisfaction, nurse, care.

\section{INTRODUCTION}

Assessment of satisfaction with nursing care is determined by the manner of nursing, performance of instrumental activities, environmental quality [1] and kindness, politeness, concern and caring [1, 2], as well as professionalism, support provided during education, and communication skills [1]. Additional importance is played by the hospital environment, i.e. sanitary conditions in the ward, frequency and quality of meals, number of staff, access to media, and respect for patients' rights [3]. The patients' satisfaction and subjective feeling about medical care is closely related to the quality of care [4]. Assessment of nursing care is related to the improvement of service quality and mobilizes professional care and professional development [5].

The aim of this study was to assess the satisfaction level with nursing care among patients staying in the neurology department.

\section{MATERIAL AND METHODS}

The study was conducted in 2021 in the Department of Neurology at the $5^{\text {th }}$ Military Clinical Hospital with Polyclinic in Cracow. After receiving the necessary information on the purpose and course of this study, 81 patients who gave their free and informed consent were selected to participate in the study. The study involved $59 \%$ of women and $41 \%$ of men. Among the respondents, $46 \%$ were between 41 and 65 years of age, also $46 \%$ of the respondents had higher education. Most patients, $60 \%$, were in a relationship. Individuals who were professionally active accounted for $58 \%$ of the total respondents. The duration of stay in the ward ranged from 2 days to a month, and the average number of nights spent by patients in the ward during this stay was 7.8.

A diagnostic survey method was used to conduct the study. The author's survey questionnaire and the 
Polish version of the Newcastle Satisfaction with Nursing Scale (NSNS-PL) were used as tools. The scale allows the patient to assess nursing care and satisfaction with care on a Likert scale (up to 7 and 5 points, respectively), and includes questions regarding demographics and duration of hospital stay. The scale also has 2 questions relating to the overall assessment of patient satisfaction with nursing care, as well as the overall stay on the ward [6]. The author's survey questionnaire allowed us to collect sociodemographic data and answers to questions related to the stay in the ward. Statistical analysis was carried out in Statistica 10 software using the Kruskal-Wallis, Mann-Whitney $U, \chi^{2}$ tests. The statistical significance level was set at $p<0.05$.

\section{RESULTS}

The mean nursing care experience score was 77.69 $(\mathrm{SD}=13.48)$ (Table 1$)$.

The mean score of satisfaction with nursing care was 83.674 (SD = 16.84) (Table 2).
Table 3 shows the relationships between higher values of the assessment of patients' experience with nursing care and the assessment of selected variables characterizing the nurses' work on the ward and the conditions of stay.

Table 4 shows the correlations between higher values of patients' satisfaction with nursing care and patients' assessment of selected variables related to the stay in the ward in terms of nurses' intervention and hospital environment.

The respondents assessed the nursing care received in the ward very highly $-37 \%$ of the respondents assessed it as excellent, and $49 \%$ as very good. Only $14 \%$ of respondents stated that the received care was good or sufficient.

The overall assessment of the stay in the ward was equally high $-56 \%$ of respondents assessed the stay as very good, and $26 \%$ as excellent, $16 \%$ of the respondents rated the stay as good and sufficiently good, and $2 \%$ of the respondents assessed the stay as bad.

Table 1. Assessment of the Newcastle Satisfaction with Nursing Scale (NSNS) nursing care experience

\begin{tabular}{lccccccccc}
\hline Assessment of nursing care experience & \multicolumn{10}{c}{ NSNS scale } \\
\cline { 2 - 10 } & \multicolumn{1}{c}{$\boldsymbol{n}$} & $\mathbf{x}$ & SD & Me & Min. & Max. & Q1 & Q3 \\
\cline { 2 - 10 } & 81 & 77.69 & 13.48 & 79.4 & 50.000 & 97.72 & 66.66 & 88.46 \\
\hline
\end{tabular}

n-number, $x$ - arithmetic mean, SD - standard deviation, Me - median, Min - minimum, Max-maximum, Q1 - upper quartile, Q3 - lower quartile

Table 2. Assessment of Newcastle Satisfaction with Nursing Scale (NSNS)-PL nursing care satisfaction

\begin{tabular}{lcccccccccc}
\hline Assessment of satisfaction with nursing care & \multicolumn{10}{c}{ NSNS } \\
\cline { 2 - 11 } & \multicolumn{1}{c}{$\boldsymbol{n}$} & $\mathbf{x}$ & SD & Me & Min. & Max. & Q1 & Q3 \\
\cline { 2 - 10 } & 81 & 83.67 & 16.86 & 88.15 & 26.31 & 100.00 & 75.00 & 100.00 \\
\hline
\end{tabular}

n-number, $x$ - arithmetic mean, SD - standard deviation, Me - median, Min-minimum, Max-maximum, Q1 - upper quartile, Q3 - lower quartile

Table 3. Assessment of nursing care experience and patients' assessment related to their stay on the ward

\begin{tabular}{|c|c|c|c|c|}
\hline $\begin{array}{l}\text { Variable characterizing their stay } \\
\text { on the ward }\end{array}$ & \multicolumn{3}{|c|}{ Assessment of nursing care experience by patients } & Kruskal-Wallis test \\
\hline $\begin{array}{l}\text { Quickness in filling out the documentation } \\
\text { upon admission }\end{array}$ & 56 & 20 & 5 & $\begin{array}{c}\mathrm{H}(2, N=81)=10.04962 \\
p=0.00\end{array}$ \\
\hline Politeness of the staff during admission & 65 & 14 & 2 & $\begin{array}{c}\mathrm{H}(2, N=81)=13.14184 \\
p=0.00\end{array}$ \\
\hline $\begin{array}{l}\text { Politeness of nurses towards the patient's } \\
\text { family }\end{array}$ & 65 & 15 & 1 & $\begin{array}{c}\mathrm{H}(2, N=81)=13.51880 \\
p=0.00\end{array}$ \\
\hline $\begin{array}{l}\text { Promptness of nurses' response } \\
\text { to the call (ringing) during the day duty }\end{array}$ & 56 & 24 & 1 & $\begin{array}{c}\mathrm{H}(2, N=81)=17.23513 \\
p=0.00\end{array}$ \\
\hline Availability of television services & 5 & 1 & 75 & $\begin{array}{c}\mathrm{H}(4, N=81)=10.10593 \\
p=0.03\end{array}$ \\
\hline
\end{tabular}


Table 4. Assessment of satisfaction with nursing care and patients' assessment of selected variables related to hospital stay

\begin{tabular}{|c|c|c|c|c|}
\hline \multirow{2}{*}{$\begin{array}{l}\text { Variable characterizing their stay } \\
\text { on the ward }\end{array}$} & \multicolumn{3}{|c|}{ Assessment of satisfaction with nursing care } & \multirow[t]{2}{*}{ Kruskal-Wallis test } \\
\hline & Very good & Good & Average or very bad & \\
\hline $\begin{array}{l}\text { Quickness in filling out the documentation } \\
\text { upon admission }\end{array}$ & 56 & 20 & 5 & $\begin{array}{c}\mathrm{H}(2, N=81)=20.20766 \\
\quad p=0.00\end{array}$ \\
\hline Politeness of the staff during admission & 72 & 8 & 1 & $\begin{array}{c}\mathrm{H}(2, N=81)=8.184531 \\
\quad p=0.01\end{array}$ \\
\hline $\begin{array}{l}\text { Waiting time for a place in the patient } \\
\text { room }\end{array}$ & 39 & 32 & 10 & $\begin{array}{c}\mathrm{H}(2, N=81)=16.70722 \\
p=0.00\end{array}$ \\
\hline $\begin{array}{l}\text { Politeness of nurses towards the patient's } \\
\text { family }\end{array}$ & 65 & 15 & 1 & $\begin{array}{c}\mathrm{H}(2, N=81)=14.29910 \\
p=0.00\end{array}$ \\
\hline $\begin{array}{l}\text { Promptness of nurses' response } \\
\text { to the call (ringing) during the day duty }\end{array}$ & 56 & 24 & 1 & $\begin{array}{c}\mathrm{H}(2, N=81)=19.84548 \\
\quad p=0.00\end{array}$ \\
\hline $\begin{array}{l}\text { Promptness of nurses' response } \\
\text { to the call (ringing) during the night duty }\end{array}$ & 59 & 20 & 2 & $\begin{array}{c}\mathrm{H}(3, N=81)=22.88364 \\
p=0.00\end{array}$ \\
\hline $\begin{array}{l}\text { Empathy and understanding shown } \\
\text { by nurses }\end{array}$ & 68 & 12 & 1 & $\begin{array}{c}\mathrm{H}(2, N=81)=15.20197 \\
p=0.00\end{array}$ \\
\hline Provision of information & 57 & 16 & 8 & $\begin{array}{c}\mathrm{H}(3, N=81)=28.86162 \\
p=0.00\end{array}$ \\
\hline $\begin{array}{l}\text { Cleanliness in the ward and the patient } \\
\text { room }\end{array}$ & 60 & 19 & 2 & $\begin{array}{c}\mathrm{H}(2, N=81)=6.878222 \\
p=0.03\end{array}$ \\
\hline $\begin{array}{l}\text { Hygienic conditions in bathrooms } \\
\text { and toilets }\end{array}$ & 23 & 23 & 35 & $\begin{array}{c}\mathrm{H}(3, N=81)=14.14417 \\
\quad p=0.00\end{array}$ \\
\hline Quantity and quality of meals & 17 & 31 & 33 & $\begin{array}{c}\mathrm{H}(4, N=81)=23.22804 \\
p=0.00\end{array}$ \\
\hline Ability to identify medical staff & 44 & 25 & 12 & $\begin{array}{c}\mathrm{H}(2, N=81)=20.68372 \\
p=0.00\end{array}$ \\
\hline
\end{tabular}

Assessment of nursing care was not statistically significantly dependent on the number of nurses to provide high-quality care $(p=0.07)$.

The analysis did not confirm a statistically significant difference in the assessment of nursing care experience according to gender, age, marital status of the respondents, and number of nurses on duty, but only according to education ( $p=0.03$ ). Assessment of nursing care experience had higher values among working professionals and students $(p=0.00)$.

The analysis did not confirm the relationship between the assessment of satisfaction with nursing care and gender, age, education, and professional activity of the respondents, and the number of nurses on duty. Nursing care satisfaction scores had lower values in the non-union group ( $p=0.02)$.

\section{DISCUSSION}

The patient's satisfaction results from the fulfilment of his/her expectations [7], and as a subjective evaluation of the quality of medical services refers to various aspects of hospitalization that constitute its overall image [8], including sanitary conditions in the ward, frequency and quality of meals, number of staff, access to utilities, and respect for patients' rights [3].

The study using the NSNS-PL tool showed that the mean score for experience of nursing care was 77.69 and the mean score for satisfaction with care was 83.67. Analysis of relationships between variables did not confirm significant correlations between the assessment of nursing care experience and sociodemographic variables such as gender of the respondents, their age, and marital status. Education, occupational activity, and studying were found to differentiate the evaluation of experience in the study group. This means that higher score values of experience evaluation were obtained by the respondents with secondary or higher education as well as those studying and working professionally. Satisfaction with care was not significantly dependent on gender, age of the respondents, education, or professional activity, but it was dependent on marital status. Higher scores of satisfaction with care were achieved by those who were in a relationship and widowers. Care experience scores and satisfaction scores were not dependent on the number of nurses on duty but on their behaviour and conditions on the ward.

In comparison, Marć's study in a group of patients hospitalized in a neurology department showed that the mean nursing care experience score was 67 points, while the mean satisfaction score was 73.2 points [9]. The results of the study conducted by Zarzycka et al. among patients in the neurosurgery department did not show a statistically significant relationship between satisfaction with care and the patients' age 
and education, duration of hospital stay, or number of hospitalizations. However, the evaluation of experience in providing care was dependent on education - the patients with primary or vocational education obtained higher scores in this category [10]. Kozimala et al. also addressed patient satisfaction using the NSNS tool among patients treated in non-surgical wards. The mean score of experience in providing care reached 76.8 points, and satisfaction reached 87.3 points. Statistical analysis did not confirm a significant relationship between gender, age, and education of patients and the above scores [11]. The results of the mean scores of nursing care experience and satisfaction in the study of Daszuta et al. among patients undergoing subarachnoid anaesthesia were 74.98 points vs. 64.80 , respectively. Variables such as age, gender, education, and place of residence of the respondents showed no significant relationship with experience and satisfaction with care [12]. The results of a study conducted among epilepsy patients by Manzanares et al. to evaluate the research tool, confirmed a good level of patient satisfaction with care [13].

The expertise of nurses is highly desirable in treatment teams, as emphasized by Higgins et al. Participants in the study, patients diagnosed with epilepsy, revealed greater satisfaction with the support provided by specialist nurses in this area and highlighted their greater involvement, in contrast to patients who were not under the care of specialist nurses [14]. A study that Bužgová et al. showed that patients with progressive neurological diseases who received specialist palliative care were more satisfied with the care provided [15]. Studies under the direction of the same author in a group of patients with multiple sclerosis also investigated differences between specialist palliative care and standard care. The results confirmed that patients who received specialist care expressed higher satisfaction compared to the group of patients under the care of another team [16].

The patients' health status and emerging deficits as a result of illness may also be related to the level of perceived satisfaction with care. A study conducted by Huang et al. investigated such a relationship and found that cognitive impairment (memory impairment) was associated with lower satisfaction with nursing care. The study additionally emphasized the need to identify cognitively impaired patients with communication difficulties in order to better adapt care to their needs [17]. In comparison, in a study by Szöcs et al., patients in severe condition as a result of stroke experienced lower satisfaction with care [18]. In addition to health status, the satisfaction level may also be influenced by therapeutic management. The study of Szöcs et al. cited above found that the therapeutic management such as thrombolysis had a positive effect on patient satisfaction [18]. The results of another study assessing patient satisfaction with treatment methods were presented by Hoffman et al. Participants in this study, multiple sclerosis patients who had their medication administered with a new auto-injector, reported a significant improvement in overall satisfaction due to the effectiveness and convenience of their treatment [19].

Interesting results regarding satisfaction with the management of migraine headaches were presented by Rua et al. Patients who were referred to the neurology department reported higher levels of satisfaction with their care due to, among others, contact with the medical staff, the way they were informed about their condition, and treatment methods, compared to patients referred directly for MRI [20].

Nurse education interventions may also determine patient satisfaction with care. This was shown in a study conducted by Byers et al. among post-stroke patients to evaluate the effectiveness of stroke education. Those who participated in individualized education provided by nurses were more satisfied [21]. In contrast, a study by Hong et al. involving patients with intracerebral haemorrhage found that comprehensive nursing interventions are important for both nullifying negative emotions, minimizing the risk of complications, and satisfaction with nursing care [22].

An example of a study that showed other factors determining satisfaction with care is one conducted by Borghans et al. They found that the duration of hospital stay was not related to patients' satisfaction with care. The results of higher satisfaction scores referred to such issues as the provision of information by nurses, the way information was provided, or respect for privacy [23]. Other studies have noted that providing an environment for eating and not performing other activities during that time may also be important in assessing the quality of care [24]. Karaca, in his study, assessed the response time of the nursing team, and similarly to our study, his results indicated that patients evaluated this aspect of care very highly. In addition, the results of this study emphasized the need for nurses to be sensitive to the emotions expressed by the patient, to ensure the right to information and autonomy, and stressed the importance of nurses' competence for the quality of care [25]. Satisfaction with care may also be determined by the number of nurses providing health care services. A study by Edmealem et al. showed that patients who were provided care by one nurse reported higher satisfaction compared to other patients who did not have one specific nurse. Furthermore, patient satisfaction with care is related to targeted attention to comorbidities [26].

Assessment of satisfaction with care is conducted not only in relation to direct contact with medical staff in the provision of health services, but also based on telemedicine. A study conducted by Lacritz 
et al. addressed satisfaction with a neuropsychological assessment conducted by telephone. The vast majority expressed satisfaction in the assessment, while age, gender, education, and ethnicity were not related to satisfaction. This type of professional-patient contact may be considered when face-to-face neuropsychological assessment is not possible, but it requires appropriate preparation that takes into account the timing and flexibility of the examination, the presence of distractions in the patient's environment, and possible communication difficulties [27]. In another study on e-visits among adults after stroke, Appireddy et al. showed positive patient feedback on this type of visit and at the same time highlighted the need to involve different professional groups involved in patient health services, both medical staff and health system managers to shape evidence-based e-visit guidelines [28].

\section{SUMMARY}

Satisfaction with care is considered at multiple levels of health care provision. Persons from the therapeutic team should pay attention to the procedures performed, communication with patients, possibilities of patients' perception, and their active participation in the treatment process, as well as receiving information on the state of health and therapeutic procedures and respecting their rights. These factors may determine the satisfaction level with care and thus the quality of care. In addition, it is worth paying attention to the opinions of patients regarding the conditions in which hospitalization takes place. The patients' satisfaction with care should be the goal of therapeutic interventions undertaken to improve the health of patients.

\section{CONCLUSIONS}

The patient's satisfaction with care in a neurology department is high and depends on demographic factors, the conditions of the hospital environment, and the interventions taken by nurses.

Research on patients' satisfaction with care should be continued due to its importance in creating quality of care.

\section{Disclosure}

The authors declare no conflict of interest.

\section{References}

1. Juszczak K. Czynniki wpływające na zadowolenie pacjenta z opieki pielęgniarskiej w świetle badań. Pieleg Chir Angiol 2013; 4: 115-117.

2. Jachimowicz-Gaweł D, Weber A, Leksowski K, et al. Wpływ wybranych czynników na poziom oczekiwań i zadowolenia hospitalizowanych pacjentów. Hygeia Public Health 2013; 48: 494-499.
3. Szpringer M, Dziewicz E, Pluta O. Środowisko szpitalne a samopoczucie pacjentów. Stud Med 2010; 18: 41-45.

4. Mianowana V, Bednarek A, Czekirda M. Wsparcie informacyjne a poziom satysfakcji pacjentów z opieki pielęgniarskiej. Przeds Zarz 2014; XV, cz. I: 59-72.

5. Wasilewski PT. Ocena jakości usług świadczonych przez pielęgniarki oddziałów neurologii i neurochirurgii. Zdrowie i Dobrostan 2015; XXVIII: 393-401.

6. Gutysz-Wojnicka A. Zastosowanie polskiej wersji skali zadowolenia z pielęgnacji Newcastle do oceny opieki pielęgniarskiej [rozprawa doktorska]. Uniwersytet Medyczny im. Karola Marcinkowskiego w Poznaniu, Katedra Pielęgniarstwa, Zakład Pielęgniarstwa Anestezjologicznego i Intensywnej Opieki, Poznań 2010.

7. Delura M, Posłuszna-Owcarz M, Rezmerska L. Satysfakcja pacjentów z pielęgniarskiej opieki przedoperacyjnej. Innow Pielęgniarstwie Nauk Zdr 2016; 4: 8-15.

8. Maconko M, Kopański Z, Strychar J, et al. Satysfakcja pacjenta i metody jej pomiaru. JCHC 2016; 3: 14-19.

9. Marć M, Fąfara A, Gajdek M, et al. Czynniki warunkujące wypoczynek nocny i jakość opieki pielęgniarskiej pacjenta oddziału neurologicznego. Pieleg Neur Neurochir 2017; 6: 143-149.

10. Zarzycka D, Bartoń E, Mazur A, et al. Socio-demographic and medical factors associated with patients' satisfaction with nursing care and their perception of pain. Ann Agric Environ Med 2019; 26: 298-303.

11. Kozimala M, Putowski L. Ocena satysfakcji pacjentów z opieki pielęgniarskiej w Centrum Opieki Medycznej w Jarosławiu. Ann Acad Med Siles 2009; 63: 20-27.

12. Daszuta K, Liberacka J, Ślusarz R. Jakość opieki pielęgniarskiej w ocenie pacjentów po zabiegach operacyjnych wykonanych w znieczuleniu podpajęczynówkowym. Innow Pielęgniarstwie Nauk Zdr 2018; 2: 9-20.

13. Manzanares I, Sevilla Guerra S, Lombraña M, et al. Spanish version of the satisfaction with epilepsy care questionnaire: Adaptation and psychometric properties. Epilepsy Behav 2020; 102: 106812.

14. Higgins A, Downes C, Varley J, et al. Patients with epilepsy care experiences: Comparison between services with and without an epilepsy specialist nurse. Epilepsy Behav 2018; 85: 85-94.

15. Bužgová R, Kozáková R, Bar M. The effect of neuropalliative care on quality of life and satisfaction with quality of care in patients with progressive neurological disease and their family caregivers: an interventional control study. BMC Palliat Care 2020; 19: 143.

16. Bužgová R, Kozáková R, Bar M. Satisfaction of patients with severe multiple sclerosis and their family members with palliative care: interventional study. Am J Hosp Palliat Care 2020; 1049909120985422.

17. Huang LK, Tsai JC, Lee HH, et al. Dementia screening for elderly in-patients and its association with nursing care satisfaction - an observational study. Medicine (Baltimore) 2020; 99: e18741.

18. Szőcs I, Dobi B, Lám J, et al. Health related quality of life and satisfaction with care of stroke patients in Budapest: A substudy of the EuroHOPE project. PLoS One 2020; 15: e0241059.

19. Hoffmann FA, Trenova A, Llaneza MA, et al. Patient satisfaction with ExtaviPro ${ }^{\mathrm{TM}}$ 30G, a new auto-injector for administering interferon $\beta-1 b$ in multiple sclerosis: results from a real-world, observational EXCHANGE study. BMC Neurol 2017; 17: 156. 
20. Rua T, Mazumder A, Akande Y, et al. Management of chronic headache with referral from primary care to direct access to MRI compared with Neurology services: an observational prospective study in London. BMJ Open 2020; 10: e036097.

21. Byers AM, Lamanna L, Rosenberg A. The effect of motivational interviewing after ischemic stroke on patient knowledge and patient satisfaction with care: a pilot study. J Neurosci Nurs 2010; 42: 312-322.

22. Hong Y, Yan H, Wurichayihu, et al. The effects of comprehensive nursing interventions on the negative emotions, quality of life, and nursing satisfaction in intracerebral hemorrhage patients. Am J TransI Res 2021; 13: 4860-4867.

23. Borghans I, Kleefstra SM, Kool RB, et al. Is the length of stay in hospital correlated with patient satisfaction? Int I Qual Health Care 2012; 24: 443-451.

24. Beck M, Birkelund R, Poulsen I, et al. Supporting existential care with protected mealtimes: patients' experiences of a mealtime intervention in a neurological ward. J Adv Nurs 2017; 73: 1947-1957.

25. Karaca A, Durna Z. Patient satisfaction with the quality of nursing care. Nurs Open 2019; 6: 535-545.

26. Edmealem A, Asfaw Y, Ademe S, et al. Patient's satisfaction and associated factors towards nursing care in Dessie Referral Hospital, Northeast Ethiopia. Clin J Nurs Care Pract 2019; 3: 053-058.

27. Lacritz LH, Carlew AR, Livingstone J, et al. Patient Satisfaction with Telephone Neuropsychological Assessment. Arch Clin Neuropsychol 2020; 35: 1240-1248.

28. Appireddy R, Khan S, Leaver C, et al. Home virtual visits for outpatient follow-up stroke care: cross-sectional study. J Med Internet Res 2019; 21: e13734. 